\title{
Neuroblastoma pada Anak Usia 7 Tahun Laporan Kasus
}

\author{
Sri Mulatsih, Vicka Farah Diba \\ Bagian Ilmu Kesehatan Anak, RSUP Dr. Sardjito/ FK UGM, Yogyakarta
}

\begin{abstract}
Neuroblastoma merupakan neoplasma dari sel embrional neural dan salah satu tumor padat tersering pada anak. Paling sering neuroblastoma berasal dari kelenjar supra renal, tetapi dapat juga dijumpai di sepanjang jalur syaraf simpatis. Ditemukan kasus neuroblastoma pada usia anak yang lebih tua (7 tahun). Gejala pembesaran perut merupakan gejala awal yang harus diwaspadai adanya suatu tumor jaringan padat neuroblastoma. Perjalanan sangat cepat, dengan ditandainya penyebaran di rongga pleura, kelenjar getah bening dalam waktu satu bulan. Semua hasil analisis gejala klinis dan pemeriksaan penunjang sangat mendukung diagnosis neuroblastoma stadium IV. (Sari Pediatri 2009;10(5):292-5).
\end{abstract}

Kata kunci: neuroblastoma anak

$\mathrm{T}$

umor padat malignan harus dipikirkan pada setiap anak apabila pada pemeriksaan fisik ditemukannya masa intra abdomen. Usia anak dapat memberikan petunjuk diagnosis yang penting. Pada masa neonatal umumnya tumor berasal dari ginjal yaitu tumor Wilm's atau neuroblastoma sementara pada anak yang lebih besar masa abdomen pada umumnya berhubungan dengan leukemia dan limfoma yang disertai dengan perbesaran hati dan limpa. ${ }^{3}$

\section{Alamat Korespondensi:}

Dr. Sri Mulatsih, Sp.AK, Bagian Ilmu Kesehatan Anak, RSUP Dr. Sardjito/FK UGM. Jl. Kesehatan No.1, Sekip utara, Yogyakarta. Tel: (0274) 553142, Fax: (0274) 583745, e-mail: smulat@gmail.com
Neuroblastoma, merupakan neoplasma yang berasal dari sel embrional neural dan salah satu tumor padat tersering yang dijumpai pada anak. Rata-rata terdapat 8 kasus baru per tahun pada anak di bawah usia 16 tahun dengan rata-rata usia tersering sekitar 2 tahun. Neuroblastoma paling sering berasal dari kelenjar supra renal, tetapi dapat juga dijumpai di sepanjang jalur saraf simpatis. ${ }^{2}$

\section{Laporan kasus}

Seorang anak perempuan usia 7 tahun, datang dengan keluhan perut membesar, batuk dan sesak nafas. Keluhan perut membesar dimulai sejak 2,5 bulan sebelum masuk rumah sakit disertai dengan benjolan sebesar telur puyuh pada selangkangan dan leher yang tidak terasa nyeri, panas atau kemerahan. Keluhan perut membesar juga disertai dengan demam 
naik turun, pucat, dan penurunan berat badan $3 \mathrm{~kg}$ dalam sebulan, tidak dijumpai keluhan pada defekasi maupun berkemih. Perut semakin membesar, disertai dengan keluhan batuk yang muncul kurang lebih mulai 2 minggu dan sesak nafas dirasakan terutama jika anak berbaring. Benjolan di selangkangan dan leher tidak bertambah besar, keluhan demam, pucat serta penurunan berat badan menetap. Dari riwayat keluarga tidak dijumpai riwayat keganasan dan sakit tuberkulosis.

Pada pemeriksaan fisik dijumpai anak dalam keadaan sesak nafas, kompos mentis, gizi kurang, pucat, asites, dan edema pada labia mayora tetapi tidak dijumpai edem pada ekstremitas dan palpebra. Dijumpai efusi pleura sinistra, dengan masa abdomen teraba ukuran $5 \times 5 \times 6 \mathrm{~cm}$, mulai dari regio epigastrium ke arah inguinal dengan permukaan rata, padat, terfiksasi dan nyeri tekan. Limfadenopati pada regio inguinal dan servikal berukuran diameter $2-3 \mathrm{~cm}$, padat, terfiksasi, tidak nyeri, tidak merah, dan tidak terasa panas. Hepatomegali dan splenomegali sulit dinilai pada pemeriksaan fisik.

Hasil pemeriksaan laboratorium menunjukkan anemia normositik normokromik, trombositosis, peningkatan laju endap darah, dan hipoalbumin. Pemeriksaan apusan darah tepi juga dijumpai trombositosis dengan gambaran anemia dan tidak dijumpai sel blast.

Dari pemeriksaan radiologis dada dijumpai efusi pleura masif sinistra yang mendorong trakea dan mediastimum ke kontralateral (Gambar 1). Berdasarkan pemeriksaan fisik dan radiologi dada dilakukan pemasangan water scale drainage (WSD) pada pasien dan keluar cairan pleura serohemoragis dengan cairan eksudat. Hasil analisis PA cairan pleura dijumpai radang granulomatous, tidak dijumpai sel keganasan, pewarnaan (bakteri tahan asam (BTA) negatif, biakan bakteri selain BTA negatif, hasil biakan sputum BTA tiga kali pada pagi hari negatif. Tuberkulosis (TB) skor 4 berdasarkan ditemukan demam lebih dari 2 minggu, gizi kurang, efusi pleura pada radiologis dada sugestif TB dan perbesaran kelenjar. Pemeriksaan CT scan toraks dijumpai hidropneumotoraks sinistra, kolaps pulmo sinistra, lymphadenopathy supra clavicular, asites dan tidak dijumpai metastase sel keganasan (Gambar 2).

Pemeriksaan CT scan abdomen menunjukkan kalsifikasi supra renal, penekanan masa dari atas mendesak ginjal ke bawah dan dijumpai masa di para aortici dan para iliaca, tidak tampak kelainan pada hepar kandung empedu, limpa, kedua ginjal, pankreas, kandung kemih, ovarium dan rektum. Dari hasil $C T$ scan abdomen disimpulkan diagnosis neuroblastoma (Gambar 3.)


Gambar 1. Foto radiologis dada: Dijumpai efusi pleura masif sinistra mendorong trakea dan mediastinum ke kontralateral.
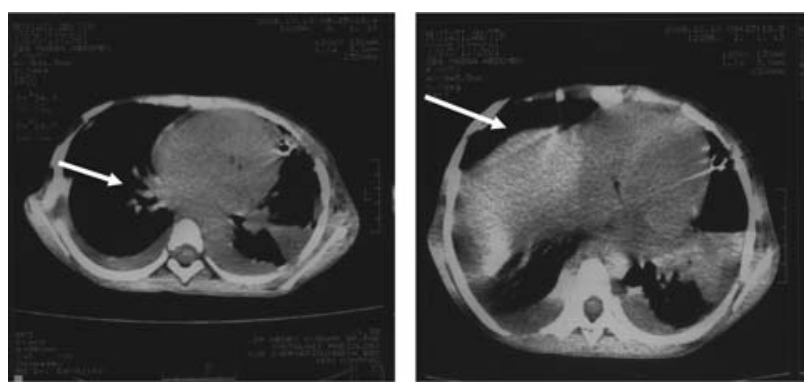

Gambar 2. CT scan toraks

Dijumpai hidropneumotoraks sinistra, kolaps pulmo sinistra, limfadenopati supra klavikular, asites dan tidak dijumpai metastase


Gambar 3. CT scan abdomen

Dijumpai kalsifikasi supra renal, penekanan masa dari atas yang mendesak ginjal ke bawah, disimpulkan terdapat neuroblastoma 

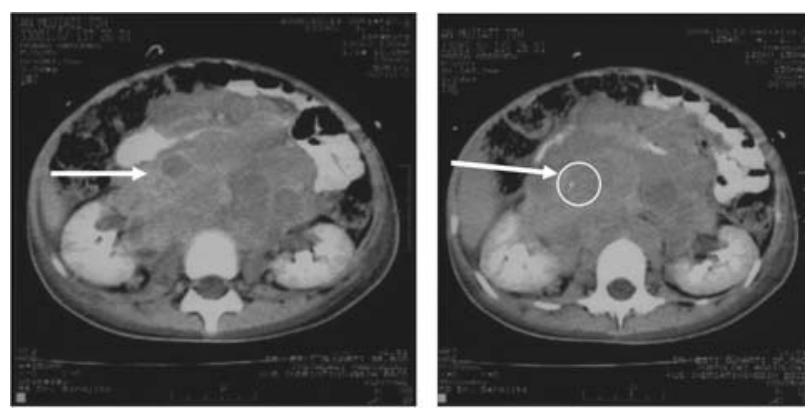

Gambar 4. CT scan abdomen

Dijumpai massa di para aortici dan para iliaka, bulat, berbatas tegas, disimpulkan sebagai metastase neuroblastoma ke kelenjar limfe regional



Gambar 5. Sitologi sel regio colli sinistra, sel-sel mengelompok sebagian tersusun roset, sebagian menyebar mendukung ke arah neuroblastoma

Dari hasil sitologi regio colli sinistra didapatkan sel-sel mengelompok sebagian tersusun roset, dan sebagian menyebar. Bentuk sel secara umum kecil, dan polimorfi. Inti bentuk bulat, oval, spindel, hiperkromatis, dan anak inti nampak jelas. Latar belakang eritrosit mendukung ke arah neuroblastoma (Gambar 5). Dari hasil aspirasi sumsum tulang tidak dijumpai metastase sel keganasan.

Dari hasil pemeriksaan penunjang tersebut maka disimpulkan anak menderita neuroblastoma stadium IV dan direncanakan mendapat kemoterapi dengan protokol neuroblastoma.

\section{Diskusi}

Neuroblastoma adalah tumor padat tersering yang dijumpai dan meliputi 7\% dari keganasan pada anak. Usia dijumpainya neuroblastoma pada anak di bawah usia 16 tahun dengan puncak pada usia 2 tahun. ${ }^{3}$ Tiga puluh tujuh persen kasus neuroblastoma terdiagnosis pada usia $<1$ tahun, 81\% pada $<4$ tahun dan 97\% pada usia 10 tahun. ${ }^{1}$ Pada laporan kasus kami, masa abdomen dijumpai pada usia 7 tahun.

Neuroblastoma adalah tumor yang berasal dari sistem saraf simpatis dan mayoritas berasal dari kelenjar medula adrenal dan ganglion simpatis. Tumor primer neuroblastoma berasal dari abdomen dengan keluhan pada umumnya terdapat masa dan nyeri pada abdomen. Anoreksia dan muntah juga dapat dijumpai. Neuroblastoma dapat bermetastase ke kelenjar limfe regional maupun ke tempat jauh, misalnya metastase pada tulang, hati, ataupun kulit. Berbeda dengan tumor padat lain, neuroblastoma jarang bermetastase ke paru. Kelenjar limfe terjauh yang sering terlibat adalah kelenjar supraklavikula, servikal, dan inguinal. ${ }^{1}$ Gejala pembesaran kelenjar limfe tersebut juga dijumpai pada kasus kami berupa masa abdomen disertai metastase pada kelenjar supra klavikular, para aorta, dan iliaka.

Keterlibatan sumsum tulang juga dapat dijumpai meskipun jarang dan pada umumnya dijumpai sel tunggal yang tidak berdiferensiasi, ${ }^{1}$ namun pada kasus kami belum dijumpai metastase pada sumsum tulang.

Secara histologis, sel neuroblastoma berbentuk bulat, kecil, dan berwarna biru yang dapat disamakan dengan sel lain baik yang berasal dari tumor primer maupun metastase. Diagnosis banding lain adalah rhabdomyosarcoma, Ewing's sarcoma, leukemia, dan limfoma. ${ }^{1}$ Pemeriksaan sitologi kelenjar regio colli sinistra ditemukan sel-sel mengelompok sebagian tersusun roset, sebagian menyebar. Sel-sel umumnya cukup kecil, cukup polimorfi, bentuk inti bulat, oval, spindel, hiperkromatis, dan anak inti tampak jelas mendukung ke arah neuroblastoma.

Pemeriksaan penunjang pada abdomen dapat ditemukan adanya kalsifikasi yang khas terdapat pada neuroblastoma, meskipun bukan sebagai faktor penentu diagnostik. ${ }^{1}$ Pada kasus kami, terdapat masa densitas homogen dan kalsifikasi supra-renal pada CT scan abdomen. Pemeriksaan rontgen atau CT scan dada dapat memperlihatkan metastase kelenjar limfe atau tumor primer di mediastinum sementara metastase pada paru 
jarang ditemukan pada neuroblastoma. ${ }^{1}$ Pada kasus ini dari hasil CT scan dada ditemukan pembesaran kelenjar supraklavikula sebagai metastase neuroblastoma dan tidak ditemukan metastase ke paru.

Penetapan diagnosis neuroblastoma secara internasional yang telah disepakati apabila ditemukan 1) Tumor unequivocal secara patologi dari jaringan tumor dengan metode standar dan kalau perlu dengan mikroskop elektron, 2) Pada pemeriksaan sumsum tulang ditemukan sel tumor unequivocal seperti synctia tumor, dan 3) Ditemukan peningkatan katekolamin yaitu VMA (vinyl mandelic acid) pada urin. ${ }^{1}$ Pada kasus kami belum ditemukan metastase sel pada sumsum tulang.

Stadium penyakit dan usia terdiagnosis merupakan faktor prognosis yang penting pada pasien. Stadium neuroblastoma menurut Children's Cancer Study Group Staging to Neuroblastoma adalah, ${ }^{2}$

- Stadium I tumor masih berada di organ asli, belum terdapat metastase

- Stadium II tumor menyebar dari organ asli tetapi tidak menyeberang dari garis tengah tubuh (metastase ipsilateral)

- Stadium III tumor sudah menyeberang dari garis tengah tubuh

- Stadium IV tumor menyebar jauh ke tulang, organ parenkim, jaringan lunak atau kelenjar limfe jauh

- Stadium IVS pasien dengan status stadium I atau II tetapi mempunyai penyebaran jauh satu atau lebih dari organ hati, sumsum tulang, dan kulit

Angka harapan hidup selama 2 tahun pada anak usia 2 tahun dengan stadium I, II, III dan IV berturutturut $95 \%, 85 \%, 60 \%$ dan $20 \%$. Usia merupakan variabel yang tidak dapat berdiri sendiri, diagnosis neuroblastoma ditegakkan pada usia yang lebih muda mempunyai prognosis yang lebih baik dan sebaliknya diagnosis pada usia lebih tua mempunyai prognosis lebih buruk. Sebagai contoh pada anak usia 6 bulan dengan stadium II mempunyai nilai prognosis 95\% sementara pada anak usia 4 tahun dengan stadium yang sama mempunyai prognosis $40 \% .^{2}$

Pada kasus ini ditemukan neuroblastoma stadium IV pada usia 7 tahun yang tentunya mempunyai prognosis yang buruk. Pada penelitian George dkk, pasien dengan neurobolastoma stadium 4 angka survival usia 12-24 bulan dengan non-amplified $N$-myc gene dan hiperploid lebih baik $(72,7 \%)$ dari pada anak yang lebih tua (26,7\%). Event free survival (EFS) untuk pasien usia $12-18$ bulan adalah $92,2 \%$ dibanding usia
19-24 bulan (37,5\%). Sementara Schimdt ${ }^{6}$ melaporkan bahwa 43 anak dengan neuroblastoma stadium IV dengan non amplification of $N$-myc gene pada pasien 12-18 bulan mempunyai EFS 74\% dibanding pasien usia 18-24 bulan (31\%). Pasien dengan amplification of $N$-myc gene mempunyai prognosis yang lebih buruk. ${ }^{7}$ Pada analisis prospektif, 5 tahun EFS pada stadium IVs pada infant adalah $92 \%$ dengan terapi minimal. ${ }^{8}$

\section{Kesimpulan}

Apabila ditemukan masa abdomen pada anak perlu dipikirkan kemungkinan tumor padat malignan. melalui diagnosis dan terapi dini akan dicapai prognosis yang lebih baik. Pemeriksaan penunjang lain seperti biopsi jaringan dan kadar katekolamin urin pada kasus kami, diperlukan untuk menegakkan diagnosis pasti neuroblastoma.

\section{Daftar Pustaka}

1. Armand BE, Garret BM. Abdominal Masses in Children : Neuroblastoma, Wilm's Tumour and other consideration, Pediatr in Review 1991;12:196-206.

2. Julio DG. Wilm's tumor and Neuroblastoma in chlidren. Pediatr in Review 1984;6:10-9.

3. Caroline H. Evaluation of the child with an abdominal mass in the children's hospital Oakland : Hematology/ oncology handbook, Mosby Handbook 2002: 124.

4. Caroline H. Neuroblastoma in the children's hospital Oakland: Hematology/ oncology handbook, Mosby Handbook 2002; 187-90.

5. George RE, London WB, Cohn S. Hyperploidy plus nonampified MYCN confers as a favorable prognosis in children 12 to 18 months old with disseminated neuroblastoma: A Pediatric Oncology Group Study. J Clin Onco2005; 23:6466-73.

6. Schmidt ML, Lal A, Seeger R. Favorable prognosis for patients 12 to 10 months og age with stage 4 nonamplified MYCN neuroblastoma: A Children's Cancer Group Study. J Clin Oncol 2005; 23:6474-80.

7. Schell M, Bergeron C. Neuroblastoma 2003. Didapat dari: www.orpha.net.

8. Schmidt ML, Lukens JN, Seeger R, Brodeur GM, Shimada H, Gerbing, RB, Stram, dkk. Biologic factors determine prognosis in infants with stage IV neuroblastoma: a prospective Children's Cancer Group Study. J Clin Oncol; 2000;18:1260-8. 